curves indicate that under certain conditions producer gas may be used in the process and that the dissociation of sodium carbonate is probably one of the controlling chemical reactions.

CARNEGIE INSTITUTION OF WASHINGTON GEOPHYSICAL, LABORATORY

WASHINGTON, D. C.

\section{A STUDY OF THE OIL FROM SUMAC (RHUS GLABRA)}

By H. W. Brubater

Received April 24, 1919

Since the demand for fats has increased so greatly and their price has reached such a high level it has become imperative that we make use of all the available sources of this most important material. A great deal of the rocky wasteland of Kansas and other states is covered with the common sumac (Rhus Glabra). It occurred to the author to make a chemical study of the oil from the sumac seed to determine its fitness as a food or for industrial purposes and the amount available.

The berries from which this oil was obtained were gathered at Manhattan, Kansas, in February I9Ig. The husks were removed from the berries by rubbing gently in a mortar and sending the material through a small fanning mill. The clean, air-dried seeds were ground in a mill and the fat extracted with dry ether in a continuous extraction apparatus large enough to hold 2 or $3 \mathrm{lbs}$. of the material. Two determinations gave an average of II.7I per cent of oil in the ground seeds. Table I summarizes the results of the physical and chemical examination of the oil.

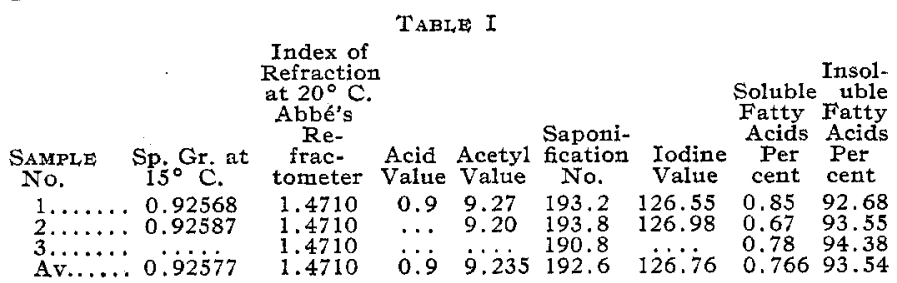

Table II gives the characteristics of the insoluble fatty acids.

\begin{tabular}{cccc} 
& \multicolumn{2}{c}{ TABLE II } & \\
Melting & Solidification & Index of & Todine \\
Point & Temperature & Refraction & Value \\
Deg. C. & Deg. C. & 1.470 & 121.8 \\
17 & 6 & Ref &
\end{tabular}

The oil of sumac has a mild odor, pleasant taste, and a deep yellow color. It is quite viscid at ordinary room temperature. Upon being cooled it thickens gradually until at $-I 6^{\circ} \mathrm{C}$. it has the consistency of soft vaseline. The oil was not cooled to its freezing point; G. B. Frankforter and A. W. Martin give the freezing point of the oil from Rhus Glabra gathered in Minnesota as $-24^{\circ}$ C. ${ }^{1}$

\begin{tabular}{|c|c|c|c|}
\hline \multicolumn{4}{|c|}{ TABLE III } \\
\hline $\begin{array}{c}\text { Oil } \\
\text { Tested }\end{array}$ & $\begin{array}{c}\text { Pexcentage Increase } \\
\text { in Weight } \\
\text { in } 7 \text { Days of a } \\
\text { Thin Film of Oil }\end{array}$ & $\begin{array}{c}\text { RISE IN TEMP } \\
\text { WITH CO } \\
\text { Initial Temp. } \\
\text { Deg. C. }\end{array}$ & $\begin{array}{l}\text { ON TREATMENT } \\
\text { CD. HiSO } \\
\text { Highest Temp. } \\
\text { Deg. C. }\end{array}$ \\
\hline $\begin{array}{l}\text { Linseed oil } \\
\text { Sumac oil. } \\
\text { Cottonseed }\end{array}$ & 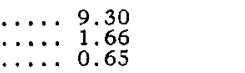 & $\begin{array}{l}20 \\
20 \\
20\end{array}$ & $\begin{array}{l}94 \\
70 \\
55\end{array}$ \\
\hline
\end{tabular}

These authors also found an iodine value of 87 which differs materially from that found for the Kansas oil,

1 Am. J. Pharm., 76 (1904), 151.
I26.76. The high iodine value would indicate that the oil should have fairly good drying qualities. This conclusion is substantiated by the results of comparative tests shown in Table III.

A small a mount of the oil mixed into a paste of the consistency of paint with sublimed white lead and spread on a plate of glass dried completely in three days.

The oil saponifies readily, giving a sodium soap of semisolid consistency.

It seems fair to conclude from the above study that sumac oil compares favorably in properties with other vegetable oils such as cottonseed oil and corn oil. It might readily find a use as an edible oil or in the soapmaking industry or as a semidrying oil in the paint industry, if it can be put on the market at a reasonable cost. The amount which might be made available can only be estimated. The author believes a conservative estimate of the amount of sumac seed in the state of Kansas alone to be $60,000,000$ lbs. containing $6,000,000$ lbs. of oil. Whether sumac can be made a practical source of oil or not can be determined only by some manufacturer situated so as to be able to handle the extraction of the oil. Those companies which extract the coloring matter from sumac or extractors of other vegetable oils are probably best situated to work out the problem.

DEPARTMENT OF CHEMISTRY

Kansas State Agricultural College ManhatTaN, Kansas

\section{COLOR STANDARDS FOR COTTONSEED OIL}

By H, V. ARNY, Charlotre Krsh aNd Frances Newmark Received Apri1 21, 1919

As is commonly known, the commercial grading of cottonseed oil is largely a matter of color, and much work has been done in attempting to find an ideal standard for the color of this commodity.

The glasses of the Lovibond tintometer have been largely used for this purpose, but I. G. Priest of the Bureau of Standards has shown ${ }^{1}$ that out of 2 I9 glasses. borrowed from cotton oil concerns and tested by him, 9 per cent of the red glasses between 0 .I and 3.0 were not matches against the Bureau of Standard sets; 5 I per cent of the red glasses between 4.0 and 20.0 were not matches; I 4 per cent of the yellow glasses. between 0.1 and 3.0 were not matched; and 40 per cent of the yellow glasses between 4.0 and 20.0 were not: matched.

This report shows that the Lovibond apparatus is not the ideal standard upon which to base a countrywide valuation of cottonseed oil. Priest, in turn, attempted to solve the problem of authentic samples of cottonseed oil enclosed in sealed vacuum cells of the proper shape and dimensions to be examined in a. colorimeter. While it is known that the color of cottonseed oil is susceptible to change when exposed to the air, Priest's preliminary experiments led him to the conclusion that a sample inclosed in a sealed vacuum cell would not be thus altered. The test of time, however, showed that such changes did take place and

1 Proc. Soc. Cotton Products Analysts, 1913, p. 6. 